\title{
KRITIK JÜRGEN HABERMAS TERHADAP PERAN DAN FUNGSI AGAMA DALAM MASYARAKAT MODERN
}

\author{
Bhanu Viktorahadi \\ Universitas Katolik Parahyangan Bandung \\ e-mail: viktorahadi@yahoo.it
}

\begin{abstract}
The wrong understanding of role and function of religion will make religion just function as instruments of legitimating those who use it irresponsibly. Therefore, it is important to take a certain paradigm to see and analyze the role and function of religion. That paradigm in its turn will restore religion in its essential role and function as a system of orientation and interpretation of the meaning of human life, as well as its relationship with God and others. The Theory of Religious Criticism and Communicative Practical Theory of Jürgen Habermas offers evaluative, reflective, and corrective critics of the role and function of religion. The fired criticism will, in turn, help religion restore its role and function as a bridge communicative and relational between human and God and the others. At the same time, religion is expected to return to its role and function in contributing to the realization of a receptive society in rational discursive rooms which in turn will enable the process of human emancipation. The further process of human emancipation is the formation of an increasingly strong personal and social identity, rooted in values or virtues derived from religion itself as the bridge that leads people to the real truth.
\end{abstract}

\begin{abstract}
Abstrak: Pemahaman peran dan fungsi agama yang keliru akan menjadikan agama sekadar menjadi alat legitimasi pihak yang memanfaatkannya secara tidak bertanggung jawab. Oleh karena itu, dibutuhkan paradigma untuk melihat sekaligus menganalisis peran dan fungsi agama supaya kembali pada hakikatnya sebagai sistem orientasi dan interpretasi atas hidup manusia pemaknaannya, serta relasinya dengan Tuhan dan sesama. Teori Kritik Agama dan Teori Praksis Komunikatif dari Jürgen Habermas menawarkan peluru-peluru kritik evaluatif, reflektif, dan korektif atas peran dan fungsi agama. Kritik yang ditembakkan tersebut pada gilirannya akan membantu agama mengembalikan peran dan fungsinya sebagai jembatan penghubung antara manusia dengan Tuhan dan sesamanya yang bersifat komunikatif dan relasional. Sekaligus dengan itu, agama diharapkan kembali pada peran dan fungsinya dalam memberi sumbangan atau berkontribusi pada upaya mewujudkan masyarakat yang reseptif pada ruangruang diskursif rasional yang pada gilirannya akan memungkinkan proses emansipasi kemanusiaan. Proses selanjutnya dari emansipasi kemanusiaan adalah pembentukan identitas personal dan sosial yang semakin kuat, yang berakar pada nilai-nilai atau keutamaan yang berasal dari agama itu sendiri sebagai jembatan yang mengarahkan manusia kepada kebenaran sejati.
\end{abstract}

Keywords: kritik; agama; komunikasi; relasional; keterbukaan 


\section{A. Pendahuluan}

Dinamika sosial politik yang mengancam kesatuan bangsa Indonesia akhirakhir ini dilansir sebagai akibat dari pemanfaatan peran dan fungsi agama secara keliru. Dalam pemanfaatan yang keliru ini agama cenderung berperan dan berfungsi sebagai sekadar ideologi. Ideologi di sini dipahami sebagai kesadaran yang palsu dan rasionalisasi dari kondisi-kondisi yang irrasional. Dalam peran dan fungsinya sebagai ideologi, agama sangat mudah digunakan sebagai alat legitimasi yang bersifat represif. Sebagai alat legitimasi, agama mudah jatuh ke dalam penyalahgunaan. Penyalah-gunaan ini pada gilirannya akan semakin menjauhkan fungsi dan peran agama yang sesungguhnya. ${ }^{1}$ Dibutuhkan upaya untuk mengkritisi peran dan fungsi agama ini supaya kembali pada hakikatnya, yaitu sebagai sistem orientasi dan interpretasi atas hidup manusia dan pemaknaannya dalam relasinya dengan Tuhan. ${ }^{2}$

Diskursus terkait peran dan fungsi agama ini telah menghangat, bahkan membuat panas para pemikir Jerman di paruh abad ke-21. Diskursus ini bahkan sempat menghidupkan panggung pemikiran filsafat dan sosiologi di Jerman selama lebih dari satu dasawarsa. ${ }^{3}$ Pada awal tahun 1960-an diskursus terkait problematika itu muncul karena agama memiliki peran sangat strategis dalam dinamika sosial hidup masyarakat. Salah satu tokoh pemikir yang berminat masuk dalam diskursus itu adalah Jürgen Habermas. Habermas adalah seorang Profesor emeritus di Universitas Heidelberg, Jerman (1961-1964) yang pada saat itu dianggap sebagai filsuf Jerman yang berpengaruh, terutama dalam persoalan ilmu-ilmu sosial. ${ }^{4}$ Habermas termasuk generasi kedua dari Mazhab

1"Samuel P. Huntington dalam tesisnya 'Clash of civilizations' menegaskan bahwa terlalu memberi tempat yang berlebihan pada peran agama akan menciptakan konflik. Yang terjadi bukanlah persaingan antara agama, bukan pula konflik yang lahir dari klaim-klaim mutlak agamaagama (monoteis) yang mengancam perdamaian, melainkan instrumentalisasi perasaan-perasaan religius melalui agitasi demi kepentingan politiklah yang menjadi penyebab terjadinya 'clash of civilizations'. Lihat A. Sunarko, "Monoteisme dan Kekerasan terhadap Yang Lain", dalam Jurnal Melintas Vol. 23 No. 1, Departement of Philosophy Parahyangan Catholic University Bandung, April 2007, h. 53.

2Lihat Bambang Sugiharto, "Pergeseran Paradigma pada Sains, Filsafat dan Agama Saat Ini", dalam Jurnal Melintas Vol. 26 No. 3, Department of Philosophy Parahyangan Catholic University Bandung, Desember 2010, h. 326-327.

${ }^{3}$ G.P. Sindhunata, Dilema Usaha Manusia Rasional: Kritik Masyarakat Modern oleh Max Horkheimer dalam Rangka Sekolah Frankfurt (Jakarta: Gramedia, 1982), h. xiv.

${ }^{4}$ Rudolf J. Siebert, The Critical Theory of Religion: The Frankfurt School, From Universal Pragmatic to Political Theory (Berlin: Mouton, 1985), h. 1. 
Frankfurt. Dalam diskursus tersebut, Habermas melihat bagaimana agama menjadi ideologi dalam arti teori kritis. Ideologi di sini dipahami sebagai kesadaran yang palsu dan rasionalisasi dari kondisi-kondisi yang irrasional. Agama menjadi ideologi antara lain karena menjadi alat legitimasi kekuasaan yang bersifat represif.

Salah satu yang memicu upaya analisis Habermas terhadap agama terkait peran dan fungsinya dalam masyarakat modern adalah rasa heranannya akan kenyataan bahwa agama-agama bisa bertahan menghadapi begitu banyak perso-alan kontingensi. Dalam hal ini, yang dimaksud dengan kontingensi adalah sesuatu yang hanya kebetulan, yang ketiadaannya tidak akan meniadakan kenyataan yang lain. Menurut Habermas, agama bisa bertahan karena sudah diimunisasi. Dalam proses imunisasi itu agama sudah dimasukkan dalam tema-tema tertentu. Selain itu, masih dalam proses imunisasi, agama juga dirasionalisasikan sedemikian rupa sehingga tertutup hatinya untuk melibatkan diri dengan penderitaan dunia dan manusia. Proses imun-isasi ini dimulai dengan dipisahkannya yang sakral dengan yang profan ${ }^{5}$. Akibat pemisahan tersebut, agama menjadi semakin jauh dari persoalan dunia. Agama menjadi tidak komunikatif lagi terhadap dunia. Praksis agama menjadi praksis yang tidak komunikatif. Bahasa yang dipakai agama menjadi bahasa yang terbatas.

Para pemikir seperti Immanuel Kant (1724-1804), Johann Gottlieb Fichte (1762-1814), dan Friedrich Wilhelm Joseph Schelling (1775-1854) telah berupaya mencari solusi atas persoalan pemisahan yang sakral dengan yang profan, yang religius dengan yang sekuler itu. Georg Wilhelm Friedrich Hegel (1770-1831) termasuk salah seorang pemikir yang telah mengusahakan pemisahan itu. ${ }^{6}$ Usaha yang dilakukannya adalah memisahkan antara alam (die Natur) dengan Roh (der Geist) yang disebutnya sebagai 'Yang Absolut' (das Absolute). Akan tetapi, usahanya tidak sampai menjawab permasalahan

\footnotetext{
5Pendalaman terkait yang sakral dan yang profan bisa menggunakan Mircea Eliade, The Sacred and The Profane (New York: Harper and Row, 1961).

${ }^{6}$ Menurut Hegel, dalam agama Yahudi Allah adalah Tuan, sedangkan manusia adalah budak yang melaksanakan perintah-Nya. Hubungan manusia ini adalah sebuah alienasi, dan menurut Hegel, alienasi ini diatasi dalam agama Kristen yang memandang Allah itu kasih, maka keterasingan manusia dari Allah dan dari sesamanya disembuhkan oleh kesatuan kasih. Akan tetapi, kemudian agama Kristen menjadi agama moralitas kewajiban (Kantianisme). Jadi, legalisme Yahudi yang pernah diatasi Kristus sekarang muncul lagi. Lihat F. Budi Hardiman, Filsafat Modern, dari Machiavelli sampai Nietzsche (Jakarta: Gramedia, 2007), h.175-176.
} 
komunikasi manusia sehari-hari. Kaum hegelian kiri (Linksehegelianismus) seperti Max Horkheimer (1895-1973), Theodore W. Adorno (1903-1969), Walter Benyamin (1892-1940), Leo Löwenthal (1900-1993), dan Erich Fromm (1900-1980) mencoba membuat tema-tema tertentu terkait persoalan-persoalan religius seperti Tuhan, dosa, cinta, keadilan, penebusan, dan keselamatan dari sisi sekuler. Tema-tema tersebut dibuat dan disusun demi mencari solusi yang sesuai dan spesifik.

Selain para filsuf, para teolog pun ikut sibuk mencari solusi atas problematika yang sakral dan yang profan ini. Teolog-teolog politis seperti Paul Tillich (1886-1965), J.B. Metz, Helmut Peukert, dan Edmund Arens mencoba memanfaatkan kategori-kategori teori ilmu pengetahuan dan teori tindakan untuk memperta-hankan kebenaran-kebenaran religius. Akan tetapi, tetap saja sejumlah kelemahan membuat pemikiran mereka tidak mampu untuk menetapkan fungsi dan peran agama secara kritis. Berangkat dari ranah diskursus itulah Habermas mencoba mengkritisi peran dan fungsi agama. Upayanya ini diawali dengan menganalisis situasi masyarakat modern.

\section{B. Teori Kritik Agama}

Habermas menganalisis situasi masyarakat modern dengan melihat cara dan strateginya mengembangkan rasio-nalitas tertentu dalam kenyataan hidupnya sehari-hari secara konkret. Habermas menilai bahwa masyarakat modern terlalu mengembangkan rasionalitas instrumental. ${ }^{7}$ Menurut Habermas, rasionalitas instrumental memunculkan masyarakat yang memiliki kesadaran yang bersifat teknologis dan teknokratis. Dalam analisisnya, Habermas melihat bahwa munculnya masyarakat semacam itu terjadi dalam dua tahap. Pertama, tahap teori sosial. Pada tahap teori sosial, kecenderungan untuk berpikir secara teknokratis mengancam dimensi reflektif dalam hidup manusia. Kedua, tahap teori pengetahuan. Pada tahap teori pengetahuan, rasionalitas intrumental ini bisa menguasai pikiran masyarakat modern. Pikiran yang dikuasai rasional

${ }^{7}$ Rasionalitas instrumental adalah rasionalitas yang mengarah pada kegunaan. Rasio sematamata dipakai sebagai instrumen atau alat untuk memperhitungkan segala kemungkinan dan peluang demi tercapainya tujuan yang subjektif, yaitu tujuan yang berguna bagi kepentingan subjek. Di sini rasio hanya menjadi alat sehingga kehilangan otonominya. Lebih gawat dari itu, rasio juga kehilangan sifat kritisnya karena mengabdi kepada tujuan semata. Dengan kata lain, rasionalitas yang direduksi. Lihat Strukturwandel der Oeffentlichekeit - Perubahan dalam Struktur Pendapat Umum (Heidelberg, 1962). 
instrumental ini memberi tempat yang kokoh pada positivisme. Padahal, positivisme selalu mengabdi dan menyesuaikan diri pada realitas yang ada. ${ }^{8}$ Akibatnya, positivisme juga tidak memberi tempat untuk aktivitias reflektif. ${ }^{9}$

Buah dua tahap analisisnya ini membuat Habermas melihat terjadinya gejala kemunduran kemampuan reflektif manusia. Padahal, refleksi atas situasi hidup sehari-hari seharusnya membantu manusia menyingkap dan mengungkap kepentingan-kepentingan mendasar dan prinsip dari hidupnya. Dengan kata lain, tanpa upaya reflektif, manusia akan kehilangan pemaknaan akan hidupnya, baik bagi dirinya sendiri, bagi masyarakat di mana ia tinggal, maupun dalam relasinya dengan Tuhan. Berangkat dari buah analisisnya ini, Habermas bermaksud mempromosikan suatu paradigma baru. Menurutnya, paradigma ini bisa memberi peluang bagi manu-sia untuk mencapai rasionalitas yang bersifat lebih komunikatif. Rasionalitas semacam itu penting untuk menyokong pembentukan identitas pribadi dan sosial manusia modern. ${ }^{10}$

Dalam mengembangkan teorinya ini Habermas menggunakan sistem pemikiran dari Hegel untuk menarik prinsip-prinsip yang akan dipakainya untuk membangun dan mempromosikan paradigma itu. Tentu saja, Habermas tidak mengambil dan menggunakan sistem pemikiran dari Hegel itu mentahmentah. Berbeda dengan Hegel yang pendekatannya bersifat teologis, Habermas

${ }^{8}$ G.P. Sindhunata, Dilema Usaha Manusia Rasional, h. 105.

'In Frankfurt usage a 'positivist' in a person who holds: (a) that an empiricist account of natural science is adequate, and (b) that all cognition must have essentially the same cognitive structure as natural science. If all theories in natural science have an 'objectifying' stucture of natural science, is to assert that all cognition is 'objectifying' cognition. So positivism can be seen as the 'denial of reflection', i.e. as a denial that theories could be both reflective and cognitive - Mazhab Frankfurt menggunakan istilah 'positivist' untuk menunjuk seorang pribadi yang berprinsip (a) bahwa suatu nilai empiris ilmu pengetahuan alam itu memadai, dan (b) bahwa semua pengertian secara esensial harus memiliki kesamaan struktur pengertian seperti ilmu pengetahuan alam. Jika semua teori dalam ilmu pengetahuan alam memiliki suatu objektivitas seperti struktur ilmu pengetahuan alam, hal itu menegaskan bahwa semua pengertian adalah pengertian yang objektif. Oleh karena itu, positivisme bisa dilihat sebagai 'penyangkalan atas refleksi' sekaligus menegaskan adanya suatu sangkalan terhadap aneka teori yang mengakomodasi sekaligus refleksi dan pengertian. Lihat Raymond Geuss, The Idea of a Critical Theory: Habermas \& the Frankfurt School (Cambridge: Cambridge University Press, 1981), h. 2.

${ }^{10}$ Rasionalitas menunjuk pada sesuatu yang dapat dipahami, ditangkap, masuk akal memiliki sifat-sifat pemikiran yang konsisten, koheren, sederhana, lengkap, teratur, terstruktur, dan logis. Lihat Lorens Bagus, Kamus Filsafat (Jakarta: Gramedia, 1996), h. 928. Konsep ini mengacu pada sebuah aliran filsafat modern yang berpandangan bahwa pengetahuan kita tidak didasarkan pada pengalaman empiris kita, melainkan pada asas-asas a priori yang terdapat di dalam rasio kita. Maka itu, rasionalisme bertolak dari aksioma-aksioma, prinsip-prinsip atau definisi-definisi umum lebih dahulum sebelum menjelaskan kenyataan. Lihat F. Budi Hardiman, Filsafat Modern, h. 301. 
bermaksud mengembangkan paradigma yang prinsipnya ditentukan subjektivitas dan praksis hidup ma-nusia itu sendiri. Dengan kata lain, Habermas lebih memilih bergerak di ranah horizontal. Sementara itu Hegel bermain di ranah vertikal. Dengan kata lain, dalam mengembangkan paradigmanya, Habermas tidak mau melibatkan "Tuhan". Paradigma yang hendak dikembangkan Habermas adalah suatu etik komunika-tif yang bersifat universal.

Akan tetapi, walaupun tidak melibatkan "Tuhan", dalam mengembangkan teorinya itu Haber-mas secara tidak langsung juga membahas persoalan agama yang tentu saja mensyaratkan relasi antara manusia dengan Tuhan. Persoalan agama harus dibahas karena Habermas hanya bisa memahami proses evolusi masyarakat modern jika dirinya memahami peran agama-agama. Oleh karena itu, dengan mengembangkan paradigma etis komunikatif ini, secara tidak langsung Habermas membuka sebuah ruang diskusi tentang peranan dan posisi agama-agama dalam dinamika kehidupan mayarakat modern.

\section{Analisis terhadap Pemahaman Mitis}

Oleh karena tidak menempatkan agama sebagai pusat analisisnya, dalam mengembangkan paradigmanya, Habermas tidak memulai dan tidak menyusun suatu de-finisi tentang 'agama'. Habermas melihat agama sebagai bagian dari kebudayaan ${ }^{11}$. Artinya, agama dipandang sebagai suatu sistem pandangan hidup yang memberikan sistem orientasi dan interpretasi atas hidup bagi penganutpenganutnya. Agama dilihatnya sebagai supra-struktur kebudayaan yang penting guna memahami kebudayaan secara lebih integral. Meskipun jelas bahwa sis-tem agama yang langsung dianalisisnya adalah kristianitas, Habermas sebenarnya tidak menunjuk agama tertentu dalam mengembangkan paradigmanya ini. Habermas memakai sejumlah ungkapan untuk menyebut agama. Suatu saat ia berbicara tentang 'sudut pandang religius dan sistem-sistem interpretasi' (religious worldviews and systems of interpretation). Di saat yang lain, ia berbicara tentang 'dongeng-dongeng tradisional' dan 'sudut pandang tradisional-metafisik'

\footnotetext{
${ }^{11}$ Elizabeth H. Nottingham menyatakan bahwa agama merupakan produk kebudayaan atau hasil pengembangan dari aktivitas manusia sebagai makhluk pencipta kebudayaan. Oleh karena itu, agama bisa dianggap sebagai sarana kebudayaan bagi manusia. Dengan sarana itu manusia sanggup menyesuaikan diri dengan pengalaman-pengalaman dalam keseluruhan lingkungan hidupnya, termasuk dirinya sendiri, anggota kelompoknya, alam, bahkan lingkungan lain yang dirasakan sebagai sesuatu yang transenden. Lihat L. David [ed.], International Encyclopedia of the Social Sciences, Jilid 13-14 (London: Collier Macmillan, 1972), h. 34.
} 
atau 'sudut pandang mistik' (traditional-mythical and reli-gious-metaphysical or mystical worldviews). Habermas juga kerap memakai istilah sejumlah 'sudut pandang pra-modern yang berpengaruh' (great pre-modern religious worldviews) untuk menyebut agama.

Habermas memakai istilah-istilah itu guna menunjukkan aspek atau sifat tertentu dari agama. Tulisan ini akan memakai istilah 'agama' dengan tetap mengingat sebutan-sebutan yang dipakai Habermas itu. Dengan memakai ungkapan-ungkapan tersebut, Habermas bermaksud melihat agama lebih secara fungsional. Dari sudut pandang fungsional inilah Habermas mempertanyakan fungsi agama dalam masyarakat modern. Peluru-peluru kritiknya ditembakkan ke arah agama guna melihat sejauh mana agama masih berfungsi dengan baik atau justru kehilangan perannya karena tidak sanggup menjawab atau menjadi solusi atas banyak persoalan manusia modern. Dengan pemahaman seperti di atas, jelas bahwa Habermas tidak memasalahkan timbulnya agama seperti dilakukan oleh Ludwig Feuerbach (1804-1672) atau Sigmund Freud (18561959). 12

Terkait fungsi dan pengaruh agama bagi masyarakat, Habermas melihat bahwa pemahaman yang bersifat mitis dari agama-agama ternyata berpengaruh dan berperan sangat besar dalam pembentukan kesadaran masyarakat modern. Menurut Habermas, fungsi mitos dalam masyarakat primitif adalah memberikan satu-kesatuan integratif dari aneka pandangan tentang hidup dengan jalan memberikan suatu 'model' atau 'pola' (an exemplary way). Pemahaman mitis ini berbeda secara opositif dengan pemahaman modern tentang dunia. ${ }^{13}$ Dari Levy-Bruhl (1857-1939),14 Habermas melihat bahwa perbedaan pemikiran mitis dan modern tidak berpengaruh pada kemampuan mengambil tindakan berdasarkan logika.

Menurut Habermas, dalam cakupan yang lebih sederhana, secara prinsip manusia dewasa yang hidup pada masyarakat primitif memiliki kemampuan yang serupa dengan manusia modern dalam hal mengambil aneka keputusan

\footnotetext{
${ }^{12}$ Feuerbach menganggap agama itu hasil proyeksi manusia yang bersumber dari keinginankeinginannya. Tuhan juga diciptakan manusia. Ajarannya ini menjadi titik pangkai banyak aliran ateisme. Freud juga mengambil alih pemikiran Feuerbach.

${ }^{13}$ Van Peursen membuat bagan tiga tahap dari strategi kebudayaan, yaitu tahap mitis, ontologis, dan fungsi-onal. Lihat A. van Peursen, Strategi Kebudayaan (Yogyakarta: Kanisius, 1976).

${ }^{14}$ Lucien Levy-Bruhl (1857-1939) adalah ahli sosiologi dan etnologi Perancis. Ia terkenal karena penyelidikan dan tulisannya tentang alam pemikiran orang-orang primitif.
} 
yang bersifat logis. Dengan kata lain, Habermas bermaksud menekankan bahwa rasionalitas pandangan mitis tidak boleh diukur begitu saja dengan menggunakan hukum-hukum logika formal yang berasal dari rasionalitas modern. Pemahaman mitis harus dinilai dari caranya menyediakan suatu sistem orientasi dan interpretasi atas hidup bagi penganutnya.

Semakin dalam mempelajari mitos, membuat Habermas semakin terkesan pada kemampuan mitos untuk memberikan suatu cara pandang dalam suatu totalitas. Habermas melihat bahwa mitos berusaha menjelaskan semua persoalan dunia secara lengkap sebagai suatu kesatuan yang utuh. ${ }^{15}$ Selain itu, mitos juga mengandung positivisme laten. Artinya, mitos justru meninggalkan pandangan-pandangan spekulatif-abstrak dalam mengamati dan memaknai realitas dunia. Dari sudut pandang mitos, hal-hal duniawi hanya diamati dan dimaknai sejauh yang sanggup ditangkap indra. Mitos tidak berusaha masuk menerobos lebih ke dalam hakikat perkara-perkara duniawi. Mitos memang pertama-tama tidak berusaha mencari dan menemukan pengertian hal-hal dunia. Mitos lebih berusaha melihat keterkaitan dan kesatuan hal-hal dunia tersebut untuk selanjutnya bisa memberi petunjuk kepada manusia bagaimana menjalani hidupnya di dunia ini. Mitos juga memberi petunjuk bagaimana manusia bisa menghadapi persoalan kontingensi atau persoalan yang timbul sebagai buah dari perjumpaan dengan pengalaman nyata atau empiris yang sekaligus bersifat kebetulan.

\section{Problem Teodisea}

Persoalan kontingensi ini merupakan persoalan yang secara serius diamati Habermas. Habermas melihat adanya kaitan yang erat antara pemahaman mitis dari agama-agama dengan persoalan kontingensi. Persoalan kontingensi ini dikenal juga sebagai persoalan teodisea. Secara sederhana, yang dimaksudkan dengan teodisea adalah pembelaan akan eksistensi atau keberadaan Tuhan. Menurut Immanuel Kant (1724-1804), seluruh usaha filsafat dalam perso-alan teodisea termasuk usaha J.M. Voltaire (1694-1778) dan G. Leibniz (1646-1716) telah gagal. ${ }^{16}$ Kant kemudian mencari jawaban atas persoalan teodisea ini dengan kembali ke agama.

\footnotetext{
${ }^{15}$ Pendalaman terkait mitos bisa dilihat misalnya pada P.S. Hary Susanto, Mitos Menurut Pemikiran Mircea Eliade (Yogyakarta: Kanisius, 1987).

${ }^{16}$ G.Leibniz (1646-1716) adalah pencipta kata 'Theodicee' (kata Perancis) yang dimaknainya sebagai 'pembenaran Tuhan' ter-hadap eksistensi kejahatan. Teodisea ini mau membela Allah
} 
Yang dimaksudkan dengan agama dalam kerangka pikir Kant adalah terutama agama Yahudi, yaitu ke pengalaman Ayub ${ }^{17}$. Ayub adalah seorang saleh dan suci. Ia adalah seorang yang taat beribadat dan korbannya diterima Tuhan. Di awal kisahnya digambarkan bahwa dirinya memiliki pelbagai macam hal yang membuatnya layak disebut sebagai seorang yang diberkati. Akan tetapi, dalam kisah selanjutnya dilukiskan bahwa kesalehan dan kesuciannya tidak menjamin dirinya terlepas dari kesengsaraan dan penderitaan. Satu per satu anaknya mati. Ternaknya juga habis. Kekayaannya ludes. Ia sendiri terkena penyakit yang sangat memalukan yang membuatnya tersingkir dari kehidupan sosial masyarakatnya. Situasi penderitaan yang dialaminya ini menimbulkan pertanyaan tentang keadilan Tuhan. Lebih jauh lagi, muncul juga pertanyaan akan eksistensi atau keberadaan Tuhan dalam situasi penderitaan manusia. Pertanyaannya, jika Tuhan yang Mahabaik itu ada, mengapa masih ada penderitaan di dunia ini, bahkan penderitaan itu menimpa orang yang taat beribadat kepada-Nya. Akan tetapi, pada dinamika permenungan akan relasinya dengan Tuhan, akhirnya Ayub menemukan bahwa dirinya tidak bisa menuntut supaya Tuhan harus berbuat adil. Sikap yang benar adalah mempertanyakan sudah sejauh mana sikap dan tindakan praksisnya itu benar di hadapan Tuhan. selain itu, gagasan lain yang hendak disampaikan lewat kisah Ayub adalah bahwa bagaimana pun relasi antara manusia dengan Tuhan selalu ditandi dengan hal-hal yang bersifat misteri. Artinya, kehendak Tuhan jauh melampaui kemampuan manusia untuk memahami dan menafsirkannya. Gagasan inilah yang digunakan Kant untuk menjelaskan perkara teodisea.

Hegel juga melihat jalan keluar ini ada pada agama, khususnya dalam iman Yahudi-Kristen akan Penyelenggaraan Ilahi (Divine Providence). Bagi Hegel, iman dan akal memang tidak pernah bertentangan. Akan tetapi, pada perkembangannya filsafat Hegel selanjut juga menjadi suatu teodisea, yaitu suatu upaya membela Tuhan dalam menghadapi ancaman dan negativitas dunia, masyarakat, dan sejarah. ${ }^{18}$ Dengan kata lain, keberadaan Tuhan menjadi semacam

melawan mereka yang tidak dapat menerima Tuhan sebab ada-Nya tidak cocok dengan segala kejahatan yang ada di dunia ini. Kata Leibniz, dari semua yang mungkin, Tuhan telah menciptakan yang paling baik. Dunia merupakan hasil maksimal. Semua kemungkinan lain itu lebih jelek. Pendapat ini sering diejek, antara lain oleh Voltaire (1694-1778).

${ }^{17}$ Ayub adalah peran utama dalam kitab Ayub dari Kitab Suci Yahudi-Kristen. Ayub tetap setia dalam penderitaannya. karena dicobai setan, walaupun ia tidak bersalah.

${ }^{18}$ Rudolf J. Siebert, The Critical Theory of Religion, h. 173-175.

JURNAL THEOLOGIA — Volume 28, Nomor 2, Desember 2017 
tempat melarikan diri dari segala macam kenyataan duniawi, terutama yang bersifat negatif.

Para pemikir lain memiliki solusi yang berbeda atas problem teodisea ini. Søren Kierkegaard (1813-1855) ${ }^{19}$ melihat bahwa persoalan teodisea bisa diselesaikan dengan iman kepercayaan kepada penyelenggaraan ilahi yang ditunjukkan dan diwujudkan dengan solidaritas terhadap mereka yang menderita. Yang dituntut dari solidaritas adalah kasih yang ikhlas berkurban, yang bersedia mengikatkan diri (engagement) secara bebas dengan mereka yang menderita.

Tak hanya para filsuf yang sibuk dengan problem teodisea ini. Para tokoh teologi kritis politis juga mengikuti penyelesaian yang serupa. Salah satunya, Max Weber (1864-1920). Weber melihat teodisea sebagai segala usaha teoretis untuk menjelaskan persoal-an penderitaan yang terjadi di dunia. Dalam pemaknaan Weberian ini, bahkan teori Marx, Freud, dan Habermas yang jelas-jelas tidak memberi tempat untuk penyelenggaraan ilahi juga bisa di-kategorikan sebagai suatu teodisea.

Berdasarkan pemaknaan Weberian itu, Teori Praksis ${ }^{20}$ Komunikatif yang digagas Habermas akhirnya juga bisa disebut sebagai semacam teodisea. Di samping itu, Habermas sendiri juga sangat menyadari bahwa interaksi komunikatif antar-manusia masih terancam persoalan kontingensi. Manusia tidak hanya mampu berinteraksi secara positif. Sebaliknya, manusia juga bisa saling menghancurkan. Sejarah manusia menunjukkan adanya 'innocent victims' atau korban-korban yang tidak bersalah. Korban-korban semacam ini bisa jadi tidak memiliki kepentingan sama sekali dalam suatu konflik. Akan tetapi, akibat konflik yang terjadi, mereka menjadi korban tanpa mengerti sebab akibat serta tujuan dari konflik tersebut. Menurut Siebert, Habermas juga tidak berhasil

${ }^{19}$ Søren Kierkegaard (1813-1855) dilahirkan di Kopenha-gen, Denmark. Alur hidupnya sangat dramatis dan diwarnai banyak penderitaan. Ia bisa disebut bapak filsuf eksistensial. Menurutnya, bereksistensi berarti merealisasikan diri dengan me-libatkan diri (engagement). Ada tiga cara bereksistensi yang dijelaskannya, yaitu sikap estetis, sikap etis, dan sikap religius.

${ }^{20}$ Istilah 'praksis' di sini digunakan dalam kerangka pikir marxistis. Oleh Karl Marx, istilah praksis tidak digunakan sejauh bertentangan dengan teori (seperti kerap terjadi dalam pemikiran Barat sejak Aristoteles), tetapi dalam ungkapan praksis justru diandaikan suatu relasi dialektis antara aksi di satu pihak dan unsur-unsur teoretis di pihak lainnya. Dengan demikian, praksis tidak sama dengan aksi yan dilakukan begitu saja. Praksis adalah aktivitas (bukan aktivisme) revolusioner. Praksis adalah aktivitas yang mengubah relasi-relasi antar-manusia, tetapi tidak dengan cara yang buta. Yang digunakan adalah cara yang mengedepankan pengertian atau pemahaman teoretis. Lihat Kees Bertens, Filsafat Barat Abad XX: Inggris-Jerman (Jakarta: Gramedia, 1983), h. 183. 
menyelesaikan dan menjawab persoalan ini. Teori Habermas menurut Siebert baru memiliki nilai universal kalau bisa menyelesaikan persoalan ini. ${ }^{21}$

\section{E. Mitos yang Mencampur-adukkan Realitas}

Walaupun tidak berhasil menjawab atau menemukan solusi atas problematika teodisea dengan paradigma yang dipromosikannya itu, Habermas tetap melanjutkan upayanya untuk menganalisis peran dan fungsi agama dalam masyarakat modern dengan mengamati dimensi mitis dalam penghayatan hidup beragama. Menurut Habermas, hal yang paling mengherankan manusia modern dari pemahaman mitis adalah usahanya untuk mempersatukan dimensi realitas yang berbeda begitu saja. Sebenarnya yang dimaksud Habermas dengan ungkapan mempersatukan adalah lebih dalam arti mencampuradukkan. Dalam upayanya mengatasi persoalan kontingensi atau persoalan kebetulan dalam dinamika kehidupan manusia, mitos cenderung mencampuradukkan dimensi alam dengan rohani (nature and spirit) dan dimensi alam dengan kebudayaan (nature and culture). Padahal, manusia modern beranggapan bahwa dimensi-dimensi ini tidak bisa dicampur-adukkan begitu saja.

Dalam pandangan mitis yang mencampur-adukkan alam dengan kebudayaan itu, setiap fenomena berhubungan deng-an fenomena lainnya karena daya-daya mitis. Misalnya, pertanyaan mengapa gunung meletus dijawab dengan gagasan bahwa penunggu gunung tersebut sedang marah. Akibat gagasan yang diajukan bersifat mitis, penyelesaian problematika yang dianggap manjur adalah dengan upaya magis. Misalnya, supaya gunung itu berhenti meletus, masyarakat sekitarnya harus memberikan persembahan yang disukai sang penunggu yang sedang marah itu. Dengan kata lain, pandangan semacam itu sangat membuka peluang penyelesaian problem teo-disea bagi masyarakat mitis dengan usaha-usaha magis ${ }^{22}$. Tentu saja, cara ini sekadar mengandalkan adanya situasi-situasi kebetulan dan tidak menjamin seratus persen bahwa problem akan benar-benar terselesaikan dengan baik.

Selanjutnya menurut Habermas, tidak adanya diferensiasi antara alam dengan roh dan kebudayaan itu akan menutup kemungkinan adanya orientasi

\footnotetext{
${ }^{21}$ Rudolf J. Siebert, The Critical Theory of Religion, h. xii dan h.180-181.

${ }^{22}$ Pendalaman terkait usaha-usaha magis lihat misalnya Rachmat Subagya, Agama Asli Indonesia (Jakarta: Yayasan Cipta Loka Caraka, 1981), h. 105-106.
} 
tindakan yang bisa disebut rasional oleh kriteria modern. Pencampur-adukkan alam dengan ke-budayaan dianggap mencampurkan dua dimensi yang berbeda secara realitas, yaitu antara yang bersifat fisik dengan lingkungan sosio-budaya dan antara benda-benda (objek) dengan manusia sebagai subjek. Pencampuradukkan ini mengakibatkan sejumlah praktik keyakinan manusia terkait dengan agama. Misalnya, pandangan bahwa penyakit fisik atau bencana alam adalah akibat dosa manusia. Ketidak-sanggupan manusia menangani alam secara fisik dianggap berhubungan dengan moralitas.

Dalam analisis Habermas, pencampur-adukkan alam dengan kebudayaan selain merupakan pencampur-adukkan konseptual antara dunia alam yang objektif dengan dunia batin-dunia sosial-dunia kebudayaan yang intersubjektif, ${ }^{23}$ juga menandakan kurangnya diferensiasi antara bahasa dengan dunia (language and world). Manusia modern memahami bahwa ber-bicara tentang kerja tidak sama dengan bekerja, berbicara tentang cinta tidak sama dengan bercinta. Sebaliknya, masyarakat mitis tidak terlalu bisa membedakan antara media bahasa dengan isinya. Mereka juga tidak membedakan antara 'inter-nal meaning' dengan 'external connection' dari benda-benda ${ }^{24}$. Habermas melihat soal ini dengan mengambil contoh hubungan antaran 'nama' dengan hal yang ditunjuknya dalam kepercayaan magis. Kepercayaan seperti itu tidak membedakan 'nama' dan hal yang ditunjuknya. Nama tertentu misalnya tidak boleh diucapkan sembarangan. Dalam adat tertentu misalnya seorang pemimpin tak boleh disebut dengan nama aslinya. Pemimpin itu harus disebut atau dipanggil dengan gelar-gelar tertentu yang mengungkapkan martabatnya. Jika terjadi pelanggaran atas kesepakatan ini, si pelaku pelanggaran akan mendapatkan hukuman. Ketidak-sanggupan membedakan media bahasa dengan isinya ini pula yang memunculkan ungkapan 'kualat' atau 'pamali' dalam arti bahwa tindakan keliru terkait penyebutan nama akan mendatangkan malapetaka atau hal-hal negatif yang tidak diinginkan.

\section{F. Validitas Ekspresi Simbolis}

Hal lain yang dilihat Habermas dari pemikiran masyarakat primitif adalah tidak adanya konsep yang tepat untuk validitas non-empiris yang oleh manusia

23Perbedaan empat dunia ini dari Habermas, yaitu the world of nature, the inner world, the social world, dan the cultural world. Lihat Rudolf J. Siebert, The Critical Theory of Religion, h. 184.

${ }^{24}$ Ibid., h. 185. 
modern dihubungkan dengan ekspresi-ekspresi simbolis. Masyarakat primitif mengacaukan validitas dengan efektivitas empiris dengan cara yang naif dan hampir tanpa refleksi. Sebaliknya, ma-nusia modern membuat kategori atas validitas. Ada sejumlah validitas. Antara lain, validitas kebenaran dalam kaitan dengan dunia alam, validitas kejujuran dalam dunia batin, kebenaran normatif dalam dunia sosial, dan nilai rasa dalam dunia budaya. Di-ferensiasi validitas ini tidak begitu jelas dalam masyarakat primitif. Pandangan yang demikian ini menyulitkan penilaian manusia modern terhadap sistem pemahaman masyarakat primitif mitis. Sementara itu, Habermas mengakui bahwa dalam pandangan tradisional tersebut masih terdapat pecahan-pecahan rasionalitas yang masih bisa dianalisis dan dikritik atas dasar argumentasi. Oleh karena itu, validitas pemikiran dan sistem orientasi serta interpretasi masyarakat tradisional masih bisa, bahkan harus dinilai berdasar argumentasi tersebut dan bukan atas dasar wibawa otoritas dan tradisi suci.

Menurut Habermas, diskursus ${ }^{25}$ terkait persoalan validitas tersebut selanjutnya harus berdasarkan konsep-konsep formal sehingga terbuka untuk suatu diskursus teoretis maupun praktis. Pengakuan validitas ini juga mensyaratkan adanya pra-pemahaman yang sama, dunia dan sudut pandang yang identik, dan juga sikap rasional dari partner-partner yang terlibat dalam diskursus tersebut. Menurut Siebert, asumsi bahwa diskursus tersebut dapat dilaksanakan oleh partner-partner yang setara rasionalitasnya adalah asumsi yang terlalu optimistis. Nyatanya rasionalitas yang dimiliki manusia tidak selalu sama. Rasionalitas manusia tidak bisa dijadikan sesuatu yang absolut. Tidak sulit melihat betapa sejarah manusia dinodai dan dirusak oleh tindakan-tindakan yang irrasional. Asumsi yang terlalu optimistis akan rasionalitas manusia ini merupakan salah satu kelemahan teori Habermas. ${ }^{26}$

${ }^{25}$ Dalam Theorie des kommunikativen Handeln, Habermas tidak lagi memusatkan diri pada kritik, melainkan pada bentuk argumentasi lain yang disebutnya 'diskursus' (der diskurs). Habermas memahami konsep kritik secara baru sebagai salah satu bentuk argumentasi yang tidak bertujuan untuk menghasilkan konsensus. Sebaliknya, diskursus adalah bentuk komunikasi reflektif dengan niveau yang tinggi dengan menggunakan argumentasi rasional untuk mencapai suatu konsensus tanpa paksaan. Lihat F. Budi Hardiman, Filsafat Fragmentaris (Yogyakarta: Kanisius, 2007), h. 118-119.

26"Habermas is fully aware of the fact that the enlightenment tradition in which he stands like all other critical theorist, has failed to console people in the face of terror and horror of nature and particularly on society, states, and history - Habermas sangat menyadari kenyataan bahwa tradisi pencerahan yang menjadi tempatnya berpijak, seperti halnya semua teori kritik yang lain, telah gagal untuk menyenangkan masyarakat saat menghadapi teror dan horor dari kenyataan alamiah dan secara khusus dari masyarakat, negara, dan sejarah." Lihat Rudolf J. Siebert, The Critical Theory of Religion, h. xi. 
Habermas masih melanjutkan analisisnya tentang pemahaman mitis. Ia menilai bahwa dengan tidak adanya diferensiasi antara bahasa dengan kenyataan yang ditunjuknya, pemahaman mitis mempengaruhi proses dogmatisasi dalam agama-agama. Dogmatisasi adalah proses membakukan kenyataan dengan perumusan bahasa tertentu. Usa-ha pembakuan ini sayangnya sering menjadi suatu pembekuan. Hal-hal yang sudah dinyatakan sebagai dogma kemudian tak terbuka lagi untuk suatu dis-kursus rasional. Habermas ingin mendobrak situasi ini. Intensinya adalah untuk mendorong tumbuhnya masyarakat yang lebih reseptif untuk suatu diskursus rasional yang memungkinkan emansipasi manusia, yang mendukung pembentukan identitas pribadi dan sosial individu dalam masya-rakat. Agama akan dianggap irrasional dan usang kalau tidak mendukung proses tersebut. Dengan basis alasan tersebut, Teori Kritik Agama menjadi upaya Habermas untuk membuka kesadaran manusia akan ancaman dari masyarakat, termasuk dari agama terhadap subjektivitas manusia.

Dalam rangka membela subjektivitas manusia inilah Habermas menekankan perlunya proses demitologisasi. Teorinya menjadi suatu kritik atas mitologi. Habermas menilai bahwa dalam dunia mitis, manusia belum belajar untuk menyatakan identitas 'aku'-nya. Identitas pribadi baru diperoleh jika belenggu mitos bisa dipatahkan. Selain kritik atas mitologi, Habermas juga masih menyampaikan sejumlah kritik terhadap pandangan hidup mitis yang dianggapnya terdapat di dalam agama-agama. Habermas membahas sifat ketertutupan sistem pemahaman mitis karena kurangnya diferensiasi terhadap dunia. Ketertutupan ini juga dikarenakan kurangnya sikap reflektif dalam sistem mitis. Masyarakat mitis tidak memahami bahwa pandangan mitis mereka merupakan suatu sistem interpretasi terhadap dunia. Mereka tidak bisa membedakan antara hal-hal yang merupakan dunia alam objektif dari hal-hal yang merupakan dunia subjektif. Mereka juga tidak bisa membedakan yang simbolis dan yang sungguh nyata, yang bisa dikritik dan harus direvisi. Kritik-kritik terhadap pemahaman mitis ini diaju-kan tanpa menutup mata bahwa rasionalitas modern juga memiliki kekurangan. ${ }^{27}$

${ }^{27}$ Rudolf J. Siebert, The Critical Theory of Religion, h.184-185. Di sini cukuplah dimengerti bahwa Habermas mengintegrasikan kritik dan bangunan teori diskursusnya. Dalam masyarakat demokratis, praksis diskursus itu akan membangun suatu sikap yang menghargai kekuatan argumentasi yang lebih baik sehingga berbagai manipulasi 'ideologis' itu sendiri pada gilirannya akan diperiksa secara publik dalam arena diskursus rasional yang bersifat publik. Lihat F. Budi Hardiman, Filsafat Fragmentasi, h. 119. 


\section{G. Penilaian terhadap Pandangan Religius Tradisional}

Meskipun jelas berpijak di pihak dunia modern dengan pandangan hidup yang sekuler, Habermas tetap mengakui bahwa pandangan hidup mistis religius tradisional juga memiliki nilai-nilai dan sikap positif. Pandangan religius tradisional dalam sejarah jelas sudah berusaha mengartikulasikan persoalan-persoalan eksisten-sial yang terpenting. Misalnya, persoalan kelahiran dan kematian, penyakit, keinginan manusia, rasa salah, cinta, solidaritas, dan kesepian. Pandangan religius tidak bisa, bahkan tidak boleh sekadar dinilai dari sudut pandang kerja dan rasionalitas instrumentalis, tetapi lebih-lebih dari sudut pandang pengakuan, interaksi, inter-subjektivitas, dan rasionalitas praktis. Terutama dari sudut pandangan interaksi dan rasionalitas komunikatif inilah pandangan hidup religius tradisional sanggup mengartikulasikan persoalanpersoalan hidup yang eksistensial dan kontingen.

Menurut Habermas, jika rasionalitas masyarakat religius tradisional hendak dinilai, penilaiannya harus berbasis pada kemampuan masyarakat itu menghadapi persoalan-persoalan hidup yang eksistensial dan kontingen tersebut. Manusia modern tidak boleh menilai masyarakat tradisional dari sudut pandang ilmu dan teknologi dunia modern. Tidak tepatlah menilai rasionalitas bentuk-bentuk pandangan hidup dari kemampuan kognitifnya saja. Ukuran yang bisa dipakai adalah sejauh mana pandangan hidup tersebut mampu memberi pengertian yang bisa diterima oleh penganut-penganutnya terkait persoalan-persoalan hidup yang eksistensial dan kontingen tersebut. Jawaban atas pertanyaan-pertanyaan tersebut memang bisa berbeda-beda.

Sementara mengakui kemampuan pandangan religius dalam upaya menjawab persoalan hidup yang ek-sistensial tersebut, Habermas tidak ingin terlibat lebih jauh membicarakan aspek material dari sistem religius tersebut. Minat dan perhatian Habermas dalam soal agama tertuju sebatas pada aspek formalnya. Habermas tertarik untuk menganalisis bagaimana sikap agama dalam menghadapi persoalan-persoalan tersebut. Dalam analisisnya, Habermas menilai bahwa agama-agama bersikap irrasional terhadap realitas. Hal itu di-amatinya misalnya dari sikap agama menghindari, bahkan mengabaikan realitas. Menurut Habermas, agama tidak mencoba melihat, menghadapi, dan memahami persoalan hidup secara terbuka. Pandangan hidup religius memang mencoba menjawab persoalan-persoalan eksistensial. Akan tetapi, jawabannya tidak berasal dari keberanian untuk menghadapi secara langsung persoalan- 
persoalan tersebut. Ada sikap yang kontradiktif dan inkonsisten. ${ }^{28}$ Dalam pandangan Habermas, irrasionalitas pandangan hidup religius itu mencapai puncaknya saat pandangan hidup religius menjadi suatu teodisea, dalam arti menjadi suatu apologi terhadap situasi dunia. Ada sikap membela Tuhan dalam situasi ketidakberesan dunia. Akan tetapi di lain pihak, sikap ini juga berarti membela dan membenarkan dunia yang tidak beres tersebut.29

Pada titik ini Teori Kritik Agama Habermas agaknya kurang melihat bahwa kekurangan pandangan religius tersebut terdapat juga dalam pandangan hidup modern yang sekuler. Titik ini juga sekaligus menjadi kelemahan teori Habermas. Teori Habermas maupun pandangan hidup modern yang sekuler juga mengandung kontradiksi dan inkonsistensi karena kurang merefleksikan sifat temporalitas dan keterbatasan manusia dan dunia. Merupakan suatu realitas bahwa dunia dan manusia tidak luput dari ancaman keterbatasan, penderitaan, dan kebinasaan. Habermas kurang memperhitungkan persoalan ini. Dalam arti tertentu, akibat mengabaikan aspek temporalitas dan keterbatasan subjektivitas manusia ini, teori Habermas juga menjadi suatu positivisme. Akan tetapi, kelemahan teori Habermas ini tentu saja tidak boleh dipakai begitu saja untuk membela agama. Alasannya, agama juga menghadapi persoalan yang serupa. Agama juga ti-dak selalu berhasil menjawab persoalan ini secara memadai.

\section{H. Agama sebagai Proses Belajar}

Habermas membahas adanya upaya untuk menentukan kriteria rasionalitas pandangan hidup dengan mengikuti pembedaan Karl Popper (1902 1994) ${ }^{30}$ tentang pandangan hidup yang terbuka dan tertutup. Ada yang berpendapat bahwa pandangan hidup religius tradisional merupakan sistem yang tertutup. Ketertutupan itu ditandai kurangnya kesadaran akan alternatif nilai lainnya, sakralitas nilai-nilai yang diyakininya, dan kekuatiran yang berlebihan akan sikap dan tindakan terhadap nilai-nilai yang dipegangnya tersebut. Sebaliknya pandangan hidup modern dinilai merupakan sistem terbuka dengan

\footnotetext{
${ }^{28}$ Dalam pemikiran Habermas, diskursus mensyaratkan para peserta diskursus itu mengakui dan menerima keunikan sesama peserta diskursus. Lihat Budiono Kusumohamidjojo, "Membangun Peradaban yang Lebih Adil," Jurnal Melintas Vol. 23, No.1, Department of Philosophy Parahyangan Catholic University, Bandung, April 2007, h. 37.

${ }^{29}$ Rudolf J. Siebert, The Critical Theory of Religion, h. 184-185.

${ }^{30}$ Karl Raimund Popper dilahirkan di Wina, Austria, tahun 1902. Ia menjadi warga negara Inggris sejak 1945. Ia terkenal dengan teori ilmu pengetahuannya.
} 
ciri-ciri yang berlawanan. Menurut Habermas, cara menilai seperti ini tak bisa dipertanggungjawabkan. Kriteria ra-sionalitas pandangan hidup kembali diukur dari kriteria ilmu pengetahuan modern.

Semangat Popperian adalah semangat ilmu pengetahuan modern yang mementingkan keterbukaan untuk belajar dan kemampuan untuk siap mengkritik sekaligus dikritik. ${ }^{31}$ Sikap reflektif yang mendasari terbentuknya teoriteori ilmu tersebut tidak bisa begitu saja dipakai sebagai kriteria untuk menilai pandangan hidup religius yang mitis. Dalam hal ini Habermas bukan seorang positivistis. Sebaliknya dalam hal ini, Habermas justru bisa dianggap membela agama terhadap serangan kaum Popperian. Dengan menentang positivisme termasuk kaum Popperian, Habermas tidak sepakat dengan sikap mereduksikan semua aktivitas manusia dalam dimensi rasionalitas fungsional. Aktivitas manusia termasuk agama tidak boleh dinilai hanya dalam kategori rasionalitas instrumental. ${ }^{32}$ Habermas justru masih membela agama dengan mengakui bahwa dalam agama masih terkandung nilai-nilai kebenaran yang bisa menjadi faktor korektif untuk rasionalitas fungsional dan pandangan yang terlalu menekankan kategori kerja serta mengabaikan kategori pengakuan dan rasionalitas komunikatif-praktis.

Habermas kemudian menjelaskan dan membela posisi pandangan hidup mitis dari serangan kaum rasionalis kri-tis. Habermas mengatakan kepada kaum Popperian bahwa sistem pemikiran mitis belum mengadakan pembedaan antara kategori kognitif-instrumental, moral-praktis, dan ekspresif-praktis dalam kaitannya dengan dunia. Oleh karena itu, pandangan hidup mitis tidak boleh dinilai tertutup karena kriteria sikapnya terhadap dunia. Pandangan hidup modern juga tidak boleh begitu saja dinilai merupakan sistem terbuka karena kriteria mentalitas ilmiahnya.

Habermas akhirnya kembali menegaskan kriteria yang dipakainya untuk menilai rasionalitas pandangan hidup, yaitu berdasarkan pembedaan kategori pengakuan dari kategori kerja. Habermas bermaksud menekankan pembedaan rasionalitas praktis dari yang fungsional. Menurut Habermas, kategori penilaian yang dipakainya untuk mempromosikan pandangan hidup berupa etik komunikatif itu juga seharus-nya dipakai untuk menilai agama.

\footnotetext{
${ }^{31}$ Lihat Antonius Subianto B., "Popper's Humanization of Theory and Method," dalam Jurnal Melintas Vol. 21, No. 3 Department of Philosophy Parahyangan Catholic University (Bandung, Desember 2005 - Maret 2006), h. 338.

${ }^{32}$ Rudolf J. Siebert, The Critical Theory of Religion, h. 185.
} 
Habermas berpendapat bahwa selain memiliki fungsi konstitutif untuk membentuk proses pemahaman, pandangan hidup juga mempunyai fungsi sosialisasi. Agama atau pandangan hidup berperan dalam proses belajar (learning process) individu untuk membentuk identitas pribadi dan sosialnya. Fungsi ini dijalani dan dipenuhi oleh sistem pandangan hidup dengan menyediakan seperangkat kategori dan anggapan pokok yang mendasar. Kategorikategori yang membentuk sistem berpikir ini tak bisa diubah begitu saja tanpa mempengaruhi identitas pribadi dan sosial individu yang mengikuti pandangan hidup tersebut. Individu cenderung untuk mempertahankan kategori-kategori tersebut dalam rangka untuk mempertahankan identitasnya. Gagasan untuk mengubah identitas bukan gagasan yang disukai.

Dalam analisis Habermas, sistem pengetahuan yang menjamin identitas pribadi dan sosial tersebut semakin menjadi formal dalam pandangan hidup yang semakin terbuka. Pengetahuan yang menjamin pembentukan identitas itu kemudian semakin menjadi bagian dari struktur kebudayaan. Selanjutnya struktur kebudayaan secara keseluruhan akhirnya semakin bersikap protektif terhadap sistem pengetahuan yang dilindunginya tersebut. Salah satu contohnya nampak dengan adanya sistem tabu. Tabu bermaksud melindungi sistem pengetahuan yang dianggap penting dari ancaman-ancaman pengalaman yang tidak sesuai dari nilai-nilai yang hendak dijaga. Meskipun ada sistem perlindungan seperti itu, pandangan hidup juga tidak lepas dari adanya revisi. Semua pandangan hidup mengalami revisi dengan cara berbeda-beda. Teori Habermas juga dimaksudkan sebagai revisi atas pandangan hidup materialisme historis yang disponsori Marx. Habermas juga bermaksud mengadakan revisi atas pandangan hidup religius tradisi-onal yang dibentuk agama-agama, termasuk agama kristiani yang menjadi latar belakang religius hidupnya.

Habermas masih meneruskan analisisnya terhadap formalisasi pandangan hidup. Dengan berdasar sosiologi agama dari Max Weber (1864-1920), Habermas kemudian berusaha untuk memahami perkembangan pandangan hidup menurut kemampuannya membentuk konsep-konsep formal mengenai dunia. Habermas juga menggunakan konsep belajar dari Jean Piaget (18961980).33 Dengan menggunakan teori yang dijemputnya dari Piaget, Habermas

\footnotetext{
33Jean Piaget (1896-1980) psikolog dan filsuf dari Swiss yang terkenal dengan psikologi perkembangannya. Pendalaman terkait teori perkembangan kognitifnya bisa dilihat misalnya dari Jean Piaget, The Construction of Reality in the Child (New York: Basic Books, 1954) dan dari Charles Shelton, Spiritualitas Kaum Muda: Bagaimana Mengenal dan Mengembangkannya (Yogyakarta: Kanisius, 1987), h. 9-23.
} 
membedakan tingkat-tingkat perkembangan kognitif. Tingkat-tingkat perkembangan itu tidak hanya ditentukan oleh isinya yang baru, tetapi juga terutama dari berkembangnya kemampuan untuk belajar. Habermas kemudian mengasumsikan bahwa hal serupa terjadi dalam perkembangan struktur pandangan hidup religius.

Dalam perkembangan struktur pandangan hidup reli-gius, terjadilah perubahan nilai-nilai. Sistem nilai yang mempengaruhi interpretasi realitas dan orientasi tindakan dari suatu tingkat pandangan hidup akan direvaluasi pada tingkat selanjutnya. Dalam sistem tersebut harus terjadi perubahan yang bersifat menyeluruh terhadap sistem nilai sebelumnya. Menurut Habermas, revaluasi sistem pandangan hidup ini merupakan perubahan ke tingkat kemampuan belajar yang lebih tinggi. Perubahan ini menyangkut peningkatan kemampuan menganalisis objek dalam kaitan dengan dunia alam, kemampuan refleksi personal dalam kaitan dengan dunia batin, pemahaman moral-praktis dalam dunia sosial, dan kemampuan berekspresi secara estetis-praktis dalam dunia budaya.

\section{Teori Praksis Komunikatif}

Berangkat dari revaluasi sistem tersebut, selanjutnya Habermas mengkategorikan sistem pandangan hidup menjadi dua. Pertama, pandangan hidup religius tradisional yang mitis yang dimiliki agama-agama dilihat sebagai sistem pandangan hidup yang tersentralisasi (centralized worldviews). Kedua, pandangan hidup modern yang sekuler sebaliknya merupakan pandangan hidup yang terdesentralisasi (decentralized worldviews).

Pembedaan ini mengikuti pembedaan dari Hegel (1770-1831). Hegel melihat bahwa pandangan hidup tradisional yang tersentralisasi ini sebenarnya untuk masyarakat yang bersangkutan bisa memberikan kegembiraan hidup dan kepastian. Pandangan hidup itu menjadi pemandu langkah-langkah mereka di dunia. Keyakinan akan hal tersebut itulah yang disebut Hegel sebagai kesadaran beragama. Menurut Hegel, manusia tidak mungkin tidak memiliki kesadaran tertentu tentang agama. Sikap tidak mengakui agama juga merupakan suatu bentuk kesadaran tertentu. Dengan filsafatnya Hegel berusaha mendamaikan pandangan hidup yang tersentralisasi dan terdesentralisasi tersebut.

Usaha Hegel mendamaikan pandangan hidup yang tersentralisasi dan terdesentralisasi itu oleh Habermas dianggap tidak memadai. Habermas berdiri di pihak pandangan hidup modern sekuler yang terdesentralisasi. Teori Praksis 
Komu-nikatif jauh lebih modern dan sekuler daripada filsafat Hegel. Habermas hanya menerima dan terbuka terhadap pandangan hidup yang tersentralisasi sejauh pandangan itu bisa dipertahankan dalam suatu diskursus yang rasional. Menurut Habermas, semakin suatu pandangan hidup tersentralisasi, semakin pandangan hidup itu sulit menerima kritik. Semakin terdesentralisasi, pandangan hidup itu semakin terbuka ke arah konsensus rasional yang komunikatif dan semakin memberikan orientasi ke arah tindakan yang rasional. Menurut Habermas, dalam transisi dari sistem pramodern ke modern, praksis komunikatif dengan diskursus yang rasional sedikit demi sedikit akan mengambil alih peran pandangan hidup yang tersentralisasi. Teori Habermas bermaksud menggantikan filsafat agama Hegel. Menurut Habermas, Teori Praksis Komunikatif yang bersifat terdesentralisasi akan mengambil alih peran pandangan hidup agama yang bersifat mitis pramodern dan tersentralisasi.

Habermas masih meneruskan penilaiannya atas perbedaan pandangan hidup pramodern dengan modern berdasarkan Teori Praksis Komunikatif. Dalam sistem pramodern yang mitis, manusia bisa kehilangan kemampuannya untuk memahami secara kritis. Menurut Habermas, dalam sistem agama-agama selalu ada bidang atau wilayah yang tak bisa dikritik lagi secara bebas dan rasional. Juga ada banyak pemecahan masalah-masalah manusiawi yang tidak terbuka lagi untuk dibicarakan da-lam suatu diskursus rasional. Rasionalitas yang terkan-dung dalam pandangan tradisional memang diakui Habermas. Sementara itu teori Habermas mengandaikan rasionalitas yang lebih tinggi yang dikandung pandangan modern yang lebih terbuka untuk suatu diskursus rasional.

Dengan latar belakang diferensiasi pandangan hidup yang tersentralisasi dan terdesentralisasi ini, Habermas kemudian menentukan kriteria untuk menilai sejauh mana suatu sistem pandangan hidup bisa mendasari suatu cara hidup yang rasional. Kriteria ini juga penting untuk menentukan unsur-unsur mana dari pandangan tradisi-onal yang masih bisa dipertahankan dan dibawa masuk ke dalam sistem modern. Menurut Habermas, kriterianya adalah kemampuan untuk membentuk konsep-konsep formal untuk dunia alam yang objektif, dunia batin yang subjektif, du-nia sosial, dan dunia kultural. Kemampuan membentuk konsep-konsep formal ini menyangkut kemampuan mengadakan diferensiasi terhadap empat segi dunia yang dihidupi manusia tersebut. Tentu saja ini menyangkut tuntutan akan tingkat refleksivitas yang tinggi. Sistem yang mendukung cara hidup yang rasional itu harus memberi tempat untuk proses dedogmatisasi. Nilai-nilai harus terbuka untuk direfleksikan, dievaluasi, 
dan direvisi secara kritis. Pada akhirnya sistem ini perlu diinstitusionalisasikan supaya semakin lama semakin terbentuk tradisi baru yang terbu-ka untuk argumentasi dan kritik rasional.

Selanjutnya Habermas mengingatkan supaya waspada terhadap bahaya utopianisme modern. Utopianisme modern ini beranggapan bahwa dari konsep pandangan nidup yang terdesentralisasi dan dari rasionalitas komunikatif saja kita sudah dapat mencapai ideal kehidupan yang sepenuhnya rasional. Ideal kehidupan tidak melulu terdiri dan ditentukan oleh jenis konsep pandangan hidup. Banyak faktor lain yang menentukan pembentukan ideal kehidupan yang rasional. Misalnya, pola-pola kebiasaan, pengelompokkan dalam masyarakat, dan 'language games'. Penentuan kategori pandangan hidup yang rasional memang panting, tetapi bukan satu-satunya faktor yang penting yang menentukan pembentukan masyarakat yang ideal.

Teori Praksis Komunikatif ingin menunjukkan kekurangan-kekurangan yang terkandung dalam pandangan hidup tradisional termasuk pandangan agama-agama dalam membangun masyarakat yang lebih rasional. Dengan itu ia ingin menunjukkan suatu jalan yang mungkin direalisasikan. Sementara itu perealisasiannya juga ditentukan faktor-faktor lain. Jalan yang mungkin direalisasikan itu adalah etik komunikatif. Etik ini adalah jalan untuk menyeimbangkan rasionalitas yang terlalu kognitif-instrumentalistis dengan rasionalitas yang lebih personal-moral-komunikatif dan malah estetis, juga merupakan jalan untuk menyeimbangkan pembentukan subyektivitas manusia yang ditentukan kategori kerja dengan kategori bahasa dan pengakuan. Intensi ini sudah kita singgung berkali-kali.

\section{J. Peluru Kritik untuk Sekularisme}

Habermas tidak hanya mengritik pandangan hidup tradisional dan agamaagama. Peluru-peluru kritik Habermas juga ditembakkan ke arah pandangan hidup modern yang sekuler. Habermas memang tidak ingin kembali ke pandangan tradisional. Akan tetapi, ia juga melihat kekurangan pandangan yang ada sekarang dalam masyarakat maju yang modern. Guna mengatasi kelemahan teorinya, Habermas memanfaatkan konsep-konsep sosiologi agama Max Weber $(1864-1920){ }^{34}$

\footnotetext{
${ }^{34}$ Max Weber (1864-1920) adalah seorang berkebangsaan Jerman yang sangat mencemaskan proses rasionalisasi dan birokratisasi masyarakat modern yang makin mencekik otonomi individu.
} 
Habermas memanfaatkan pengertian Weber terkait proses rasionalisasi pandangan hidup. Rasionalisasi yang dimaksud Weber menurut Habermas adalah proses pemisahan secara kognitif antara kebenaran dan moralitas dari pandangan hidup religius. ${ }^{35}$ Dengan demikian, rasionalisasi menjadi proses otonomisasi ke-benaran dan moralitas. Lewat rasionalisasi dan otonomisasi inilah masyarakat modern menghasilkan hukum dan etik formal yang sekuler. ${ }^{36}$ Sementara menerima pemisahan ini, Habermas tetap melihat bahwa prosesnya tetap harus dimulai di dalam kerangka sistem pandangan hidup religius itu sendiri. Habermas pun melihat dan menekankan adanya analogi antara agama dengan moralitas. Ada unsur-unsur pandangan hidup religius yang tetap sangat berharga dan perlu dipertahankan dalam moralitas modern.

Habermas kemudian melihat bahwa perkembangan pandangan hidup religius ke arah etik modern yang sekuler mengandung rasionalitas tertentu, yaitu rasionalitas da-lam memahami persoalan teodisea dan mencari pemecahannya secara lebih eksplisit. Pandangan hidup yang lebih modern antara lain mencoba mengevaluasi kembali makna penderitaan. Penderitaan dalam pemahaman mitis dilihat sebagai akibat dosa individu. ${ }^{37}$ Pemahaman yang lebih modern misal-nya bisa melihat bahwa penderitaan juga bisa disebabkan karena ketidakadilan dalam masyarakat. Akibat pemahaman yang baru ini, agamaagama kemudian bisa semakin berpihak di sisi mereka yang menderita. ${ }^{38}$

Secara umum Habermas melihat bahwa sistem kepercayaan masyarakat primitif terutama ditujukan untuk menjawab persoalan kontingensi yang bersifat kolektif. Perkembangan ke paham yang lebih modern semakin memberi tempat guna menjawab persoalan kontingensi yang lebih personal. Penilaian kembali penderitaan dan keselamatan yang dialami individu merupakan

Berlainan dengan Emile Durkheim (1857-1917) yang mendefinisikan sosiologi sebagai ilmu tentang institusi-institusi sosial, sosiologi Weber adalah ilmu tentang perilaku sosial. Pendalaman terkait perkara ini bisa dilihat pada K.J. Veeger, Realitas Sosial: refleksi filsafat sosial atas hubungan individumasyarakat dalam cakrawala sejarah sosiologi (Jakarta: Gramedia, 1985).

35Peter Comolly (ed.), Aneka Pendekatan Studi Agama, terj. Imam Khoiri (Yogyakarta: LKiS, 2002), h.277-278.

${ }^{36}$ Rudolf J. Siebert, The Critical Theory of Religion, h. 185.

${ }^{37}$ Sebagai contoh lihat Richard Leonard, "Where the Hell is God?" dalam Thinking Faith: The Online Journal of the British Jesuits, terj. F. Suryanto Hadi, dalam Rohani, No.02, Tahun ke-59 (Yogyakarta, Februari 2012), h. 35.

${ }^{38}$ Lihat E. Armada Riyanto, "Habermas' Communicative Action and the Problem of Language," dalam Jurnal Melintas Vol.17, No.54 Department of Philosophy Parahyangan Catholic University (Bandung, Desember 2001), h. 36. 
petunjuk adanya pemahaman yang lebih modern. Hal ini menurut Habermas terjadi sebagai akibat dari proses belajar (learning process). Di sini Habermas menemukan penjelasan sosiologis dengan menyatakan bahwa proses belajar itu terjadi karena bentroknya nilai keadilan dengan realitas masyarakat. Persoalan teodisea kemudian menjadi persoalan antropodisea. Artinya, yang dipertanyakan bukan lagi keadilan Allah, melainkan soal keadilan manusia. Menurut Weber, teodisea memang merupakan setiap usaha teoretis untuk menjawab persoalan penderitaan manusia. Dalam arti Weber, etik komunikatif dari Habermas juga merupakan suatu teodisea. Sementara agama-agama mencoba menjawab persoalan teodisea secara teologis, Habermas menjawabnya secara etis dengan etika sekuler.

Pemikiran Weber lainnya yang dimanfaatkan Habermas adalah pembedaan agama-agama menurut sikapnya terhadap dunia. Ada agama yang bersifat afirmatif menyepakati apa pun yang dikehendaki dunia. Di sisi lain, ada yang negatif menolak dunia. Dalam hal ini, Habermas tidak bermaksud memberi penilaian atau vonis terkait pihak mana yang benar dan pihak mana yang salah pada dua sisi yang berlawanan itu. Habermas di sini tidak berpikir mengenai sikap aktif atau pasif terhadap hidup. Yang lebih diminati Habermas adalah tentang bagaimana agama mengevaluasi dunia dalam arti sejauh mana dunia tersebut memiliki nilai positif atau negatif. Menurut Habermas, persis di sinilah letak peran dan fungsi agama yang paling penting dan substansial. Tanpa kemampuan untuk menilai sisi positif dan negatif dunia, agama akan kehilangan peran dan fungsi kritisnya dalam dinamika kehidupan masyarakat modern. ${ }^{39}$

Dengan menekankan pentingnya cinta dan etik persaudaraan, Habermas sebenarnya menggunakan postu-lat etik ${ }^{40}$ Berbeda dengan Kant, Hegel, dan teolog-teolog kristen, Habermas tidak berpaling kepada Tuhan dalam menggunakan postulat etik tersebut. Habermas ingin menyusun suatu etik sekuler yang terlepas dari kerangka agama sebagai penebusan. Etiknya tidak mau diberi pendasaran teologis. Akan tetapi, dalam intensi yang serupa yang tetap menjaga posisinya di ranah sekuler-rasional, Habermas juga berusaha menemukan dan mengumpulkan gurat-gurat rasionalitas komunikatif dalam masyarakat modern termasuk dalam pandangan hidup religius yang melatar-belakanginya. Itulah

\footnotetext{
${ }^{39}$ Rudolf J. Siebert, The Critical Theory of Religion, h. 185.

${ }^{40}$ Postulat adalah pendapat yang diterima dalam permula-an rangkaian pemikiran supaya arus pemikiran dapat dimulai. Postulat itu tidak untuk dibuktikan dan tinggal harus diterima saja.
} 
yang diusahakan Habermas dalam Teori Praksis Komunikatif maupun secara tidak langsung dalam Teori Kritik Agama-nya lewat dialog dengan banyak pemikir lainnya. Melalui paradigma yang dipromosikannya itu Habermas bermaksud menyumbangkan gagasan kritis dalam memandang, memahami, dan menyikapi praksis kehidupan beragama yang terjadi pada masyarakat modern.

\section{K. Kesimpulan}

Peluru-peluru kritik yang diarahkan Habermas terhadap agama harus dilihat bukan sebagai upaya untuk membunuh agama dan meniadakan Tuhan. Sebaliknya, peluru-peluru kritik tersebut harus dilihat sebagai ajakan untuk semakin membuka diri terhadap pelbagai kelemahan yang terdapat dalam agama dan penghayatannya sekaligus memperbaiki diri supaya bisa sesuai dengan peran dan fungsinya yang hakiki.

Terlepas dari sejumlah kelebihan dan kelemahan yang dimiliki oleh paradigma yang ditawarkan Habermas, juga terlepas dari prosesnya yang tidak memberi tempat pada pembahasan Tuhan, sejumlah butir evaluatif dan korektif atas agama bisa dijemput darinya. Pertama, agama harus mengembalikan peran dan fungsinya yang hakiki sebagai jembatan komunikatif dan relasional antara Tuhan dengan manusia dan manusia dengan manusia. Jika kehilangan fungsi komunikatif dan relasionalnya, agama hanya akan menjadi alat legitimasi pihakpihak yang memanfaatkannya secara keliru. Jika itu yang terjadi, agama tak lagi menjadi jembatan. Sebaliknya, agama menjadi tembok tebal yang memisahkan komunikasi dan relasi antara manusia dengan Tuhan dan manusia dengan sesamanya. Kedua, agama harus memakai sifat mitis yang dimilikinya bukan untuk mencampuradukkan aneka realitas yang berbeda. Sebaliknya, sifat mitis yang dimiliki agama itu justru harus menjadi kekuatannya dalam menentukan orientasi dan interpretasi para penghayatnya menuju pada kebenaran yang sejati.

Ketiga, agama harus kritis terhadap proses dogmatisasi yang terjadi di dalam dirinya. Dogmatisasi harus dikembalikan pada hakikatnya yang sejati, yaitu sebagai upaya untuk menegaskan dan menetapkan kebenara sejati supaya penghayatnya sungguh memiliki sistem kepercayaan yang pasti dan kokoh. Dengan kata lain, dogmatisasi harus tetap merupakan upaya pembakuan, bukan pembekuan. Jika yang terjadi adalah pembekuan, agama akan kehilangan 
kepekaan dan keterbukaanya akan dinamika masyarakat yang terus berkembang. Akibat lainnya adalah agama akan menjadi barang usang yang gagap dalam menyikapi dan memberi solusi atas dinamika perkembangan masyarakat yang terus berubah. Ruang-ruang untuk proses reflektif, evaluatif, dan korektif juga harus terus dibuka. Artinya, nilai-nilai substansial memang harus terus dijaga. Akan tetapi, aktualisasi dan relevansi nilai-nilai tersebut harus terus diterjemahkan sesuai dengan dinamika perkembangan yang terjadi di dalam masyarakat. Tanpa itu, sekali lagi, agama akan cepat menjadi barang usang. Keempat, agama harus memberi sumbangan atau berkontribusi pada upaya mewujudkan masyarakat yang reseptif pada ruang-ruang diskursif rasional yang pada gilirannya akan memungkinkan proses emansipasi kemanusiaan. Proses selanjutnya dari emansipasi kemanusiaan adalah pembentukan identitas personal dan sosial yang semakin kuat, yang berakar pada nilai-nilai atau keutamaan yang berasal dari agama itu sendiri sebagai jembatan yang mengarahkan manusia kepada kebenaran sejati.]

\section{DAFTAR PUSTAKA}

Bagus, Lorens, Kamus Filsafat, Jakarta: Gramedia, 1996.

Comolly, Peter (ed.), Aneka Pendekatan Studi Agama, terj. Imam Khoiri, Yogyakarta: LKiS, 2002.

David, L. [ed.], International Encyclopedia of the Social Sciences, Jilid 13-14, London: Collier Macmillan, 1972.

Eliade, Mircea, The Sacred and The Profane, New York: Harper and Row, 1961.

Geuss, Raymond, The Idea of a Critical Theory: Habermas \& the Frankfurt School, Cambridge: Cambridge University Press, 1981.

Habermas, Jürgen, Strukturwandel der Oeffentlichekeit - Perubahan dalam Struktur Pendapat Umum, Heidelberg, 1962.

Hardiman, F. Budi, Filsafat Modern, dari Macchiavelli sampai Nietzsche, Yogyakarta: Kanisius, 2007.

, Filsafat Fragmentaris, Yogyakarta: Kanisius, 2007. 
Hary Susanto, P.S., Mitos Menurut Pemikiran Mircea Eliade, Yogyakarta: Kanisius, 1987.

Kusumohamidjojo, Budiono, "Membangun Peradaban yang Lebih Adil," Jurnal Melintas Vol 23, No.1, Department of Philosophy Parahyangan Catholic University Bandung, April 2007.

Leonard, Richard, "Where the Hell is God?" dalam "Thinking Faith: The Online Journal of the British Jesuits", terj. F. Suryanto Hadi, Rohani, No.02, Tahun ke-59, Yogyakarta, Februari 2012.

Piaget, Jean, The Construction of Reality in the Child, New York: Basic Books, 1954.

Riyanto, E. Armada, "Habermas' Communicative Action and the Problem of Language," dalam Jurnal Melintas Vol.17, No. 54, Department of Philosophy Parahyangan Catholic University Bandung, Desember 2001.

Shelton, Charles, Spiritualitas Kaum Muda: Bagaimana Mengenal dan Mengembangkannya, Yogyakarta: Kanisius, 1987.

Siebert, Rudolf J., The Critical Theory of Religion: The Frankfurt School, From Universal Pragmatic to Political Theory, Berlin: Mouton, 1985.

Sindhunata, G.P., Dilema Usaha Manusia Rasional: Kritik Masyarakat Modern oleh Max Horkheimer dalam Rangka Sekolah Frankfurt, Jakarta: Gramedia, 1982.

Subagya, Rachmat, Agama Asli Indonesia, Jakarta: Yayasan Cipta Loka Caraka, 1981.

Sugiharto, Bambang, "Pergeseran Paradigma pada Sains, Filsafat, dan Agama Saat Ini," Jurnal Melintas Vol. 26, No. 3, Department of Philosophy Parahyangan Catholic University Bandung, Desember 2010.

Sunarko, A., "Monoteisme dan Kekerasan terhadap Yang Lain," Jurnal Melintas Vol. 23, No. 1, Department of Philosophy Parahyangan Catholic University Bandung, April 2007.

Van Peursen, A., Strategi Kebudayaan, Yogyakarta: Kanisius, 1976.

Veeger, K.J., Realitas Sosial: refleksi filsafat sosial atas hubungan individumasyarakat dalam cakrawala sejarah sosiologi, Jakarta: Gramedia, 1985. 